\title{
Molecular identification of trypanosome species in trypanotolerant cattle from the south of Gabon
}

\author{
Gaël Darren Maganga ${ }^{1,2, *}$, Jacques-François Mavoungou ${ }^{3,2}$, Nadine N'dilimabaka ${ }^{1}$, \\ Ivan Cyr Moussadji Kinga ${ }^{1}$, Bertrand Mvé-Ondo ${ }^{1}$, Illich Manfred Mombo ${ }^{1}$, \\ Barthélémy Ngoubangoye ${ }^{1}$, Brieuc Cossic ${ }^{4}$, Clency Sylde Mikala Okouyi ${ }^{2}$, Alain Souza ${ }^{2}$, \\ Eric Maurice Leroy ${ }^{1}$, Brice Kumulungui ${ }^{2}$, and Benjamin Ollomo ${ }^{1}$ \\ ${ }^{1}$ Centre International de Recherches Médicales de Franceville, BP 769 Franceville, Gabon \\ 2 Université des Sciences et Techniques de Masuku (USTM), Institut National Supérieur d'Agronomie et de Biotechnologies (INSAB), \\ BP 913 Franceville, Gabon \\ 3 Institut de Recherche en Écologie Tropicale (IRET-CENAREST), BP 13354 Libreville, Gabon \\ 4 SIAT-Gabon Group, BP 3928 Libreville, Gabon
}

Received 28 September 2016, Accepted 11 January 2017, Published online 1 February 2017

\begin{abstract}
The aim of this study was to provide information on trypanosome species infecting trypanotolerant cattle from southern Gabon. The study was conducted on 224 trypanotolerant cattle from three regions located in southern Gabon, using ITS1 primer-based PCR. Seventy-two (32\%) N'dama cattle were found polymerase chain reaction (PCR) positive with trypanosomes. The overall prevalence of trypanosomosis was $57 \%(63 / 110), 4 \%(4 / 100)$, and $36 \%(5 / 14)$ in the Gala section of the Nyanga ranch, the Miyama ranch, and Ossiele, respectively. Trypanosoma congolense and Trypanosoma vivax were identified. In Gala section and Ossiele, T. congolense and T. vivax were found. In the Miyama ranch, only T. vivax was identified. Mixed infections were also found. The forest $(9 \%)$ and savannah (63\%) subgroups of $T$. congolense were identified. The presence of the two subgroups was detected in 16 out of 56 cattle (29\%). T. congolense and T. vivax would appear to be the main agents responsible for bovine trypanosomosis in southern Gabon. Although trypanotolerant, N'dama cattle may serve as a reservoir, and this should be further studied. On the other hand, these trypanotolerant cattle can be reared in such tsetse infested areas, which gives them an advantage compared to other trypanosensitive breeds, and this shows that they represent a key factor in biodiversity which has to be promoted.
\end{abstract}

Key words: Trypanosoma congolense, Trypanosoma vivax, Trypanotolerant cattle, ITS1 PCR.

Résumé - Identification moléculaire des espèces de trypanosomes chez des bovins trypanotolérants du Sud du Gabon. Le but de cette étude était de fournir des informations sur les espèces de trypanosomes infectant les bovins trypanotolérants du sud du Gabon. L'étude a été menée sur 224 bovins trypanotolérants, de trois régions situées dans le sud du Gabon, en utilisant la PCR basée sur les amorces ITS1. Soixante-douze (32\%) bovins N'Dama ont été trouvés positifs en PCR pour des trypanosomes. La prévalence globale de la trypanosomose était respectivement $57 \%(63 / 110), 4 \%(4 / 100)$ et $36 \%(5 / 14)$ dans la section Gala du ranch Nyanga, au ranch Miyama et à Ossiele. Trypanosoma congolense et Trypanosoma vivax ont été identifiés. Dans la section Gala et à Ossiele, T. congolense et T. vivax ont été trouvés. Au ranch Miyama, seul T. vivax a été identifié. Des infections mixtes ont également été trouvées. Les sous-groupes forêt $(9 \%)$ et savane $(63 \%)$ de $T$. congolense ont été identifiés. Les deux sousgroupes ont été détectés chez 16 des 56 bovins (29\%). T. congolense et T. vivax pourraient être les principaux agents responsables de la trypanosomose bovine dans le sud du Gabon. Bien que trypanotolérants, les bovins N'Dama pourraient servir de réservoir, et cela devrait être davantage étudié. D'un autre côté, ces bovins trypanotolérants peuvent être élevés dans des zones infestées de glossines, ce qui leur confère un avantage certain par rapport aux races trypanosensibles, et cela montre qu'ils jouent un rôle clé dans la biodiversité, qui doit être promu.

\footnotetext{
*Corresponding author: gael_maganga@yahoo.fr
} 


\section{Introduction}

Trypanosomes are extracellular protozoan parasites of vertebrates, including domestic cattle, from tropical regions. Trypanosomes cause diseases known as trypanosomosis. In sub-Saharan Africa, cattle trypanosomosis is caused mainly by Trypanosoma congolense, Trypanosoma brucei, and Trypanosoma vivax (responsible for the disease known as nagana in cattle). African mammals harbor other pathogenic trypanosomes such as Trypanosoma simiae, Trypanosoma suis, Trypanosoma uniforme, Trypanosoma evansi (responsible for surra, trypanosomosis of Camelidae and Equidae), and Trypanosoma equiperdum (responsible for dourine, equine trypanosomosis) [30]. Trypanosomes are mainly transmitted between mammalian hosts by the bite of an infected tsetse fly (biological vectors); however, some trypanosomes can be transmitted by hematophagous Diptera (mechanical vectors) belonging to the Tabanidae, Stomoxyinae, and Hippoboscidae $[10,19,26]$. This mechanical transmission is especially known for T. vivax and T. evansi, which are mainly found in areas beyond the range of tsetse flies $[6,10]$.

In Gabon, the determination of breeding areas and the introduction of animal herds are problematic in terms of animal trypanosomosis. The few savannah areas of southern Gabon are crossed by many forest galleries and dotted with dense groves. These woodlands are the preferred shelters of tsetse that thrive in this type of environment. In addition, only little information is available on the status of bovine trypanosomosis in Gabon, especially regarding trypanosomes and tsetse species as well as the affected geographical areas. However, the presence of Glossina haningtoni and Glossina tabaniformis has been confirmed in forests and forest galleries of the Nyanga valley, southern Gabon [29]. A survey conducted in 1986 in the Okouma ranch, in the south-east, revealed the presence of G. nashi and G. tabaniformis [14]. G. palpalis palpalis was identified in different regions of the country: in the region of the Nyanga valley [29], as the main species, and during active outbreaks of human trypanosomosis, in Komo Mondah and Bendjé, in the north [11, 12], and in the north-east (Ogooué-Ivindo province) [32]. In this last region, $G$. frezili, G. fuscipes fuscipes, G. nashi, and $G$. fusca congolense have also been identified [32]. In the Nyanga valley, Trypanosoma congolense and Trypanosoma vivax have been identified in G. p. palpalis. During the Komo Mondah and Bendjé outbreaks, entomological research revealed infection of tsetse by T. brucei, T. vivax, and T. congolense. The prevalence and incidence of bovine trypanosomosis in Gabon are very poorly known. The few studies that have been conducted concern the Okouma ranch, south-east of Gabon. Trypanosoma vivax was identified in cattle at a rate of $26 \%$ using parasitological tools [14].

The aim of this study was to provide information on the circulation of trypanosome species in trypanotolerant cattle from southern Gabon and to determine the molecular prevalence of infection of these species in order to evaluate the risk of bovine trypanosomosis in the main cattle breeding regions of Gabon.

\section{Material and methods}

\section{Study areas}

The study was carried out on cattle from three areas located in two provinces of the south-east of Gabon: the Miyama ranch and the rural town of Ossiele, in the HautOgooué province; the Gala section of the Nyanga ranch in Nyanga province (Fig. 1). In addition to breeding cattle, these areas were selected because animal trypanosomosis has frequently been suspected on the basis of clinical signs.

The Miyama ranch is located about $30 \mathrm{~km}$ from Franceville, the main city. The livestock is composed of about 200 animals. N'dama trypanotolerant cattle are reared. The ranch is in a vegetation area composed of savannah and forest transitions.

The rural town of Ossiele is located in the department of Djoué, south of the town of Onga, the capital city of the department. In this region, the vegetation is also made of forest and savannah transitions. In these two regions, the surrounding watercourses are located several kilometers away, making them difficult to access by animals.

The Nyanga ranch is located in the largest savannah zone of the country in the department of Mongo-Moulengui Binza, $65 \mathrm{~km}$ from the town Tchibanga (the capital city of Nyanga province) and extends over 100,000 hectares. The Nyanga ranch includes three divisions (Nyanga, Bibora, and Voungou) divided into sections. The study was conducted within the Gala section of Nyanga division 1 .

\section{Animal sampling and blood collection}

The samples were collected in cattle, at random (without any distinction in age and sex). Animals that received trypanocide treatment (diminazene aceturate, and two weeks later isometamidium chloride) less than three months before the start of our study were excluded from sampling because the chemoprevention provides a three-month protection period. Approximately $5 \mathrm{~mL}$ of whole blood was collected from each animal in ethylenediaminetetraacetic acid (EDTA) vacuum tubes VENOJECT ${ }^{\circledR}$, by puncture of the caudal vein. EDTA tubes containing whole blood were centrifuged at $1300 \mathrm{rpm}$ for $10 \mathrm{~min}$ [7] and the plasma was recovered with buffy coat and stored at $-20{ }^{\circ} \mathrm{C}$ until shipment to the laboratory of the Centre International de Recherches Médicales de Franceville (CIRMF), Gabon, for analysis.

\section{DNA extraction and PCR}

Total DNA extraction was conducted from $200 \mu \mathrm{L}$ of a mixture plasma-buffy coat, using the Qiamp DNA Mini Kit (Qiagen) according to the manufacturer's guidelines. The DNA was stored at $-80{ }^{\circ} \mathrm{C}$ until analysis.

Trypanosome research was carried out using two PCRs. In the initial PCR, the intergenic sequence (ITS1) primers were used to amplify the partial intergenic sequence region of the ribosomal DNA (rDNA) of trypanosomes [22]. Amplification was performed in $25 \mu \mathrm{L}$ reaction volumes, containing $2.5 \mu \mathrm{L}$ 


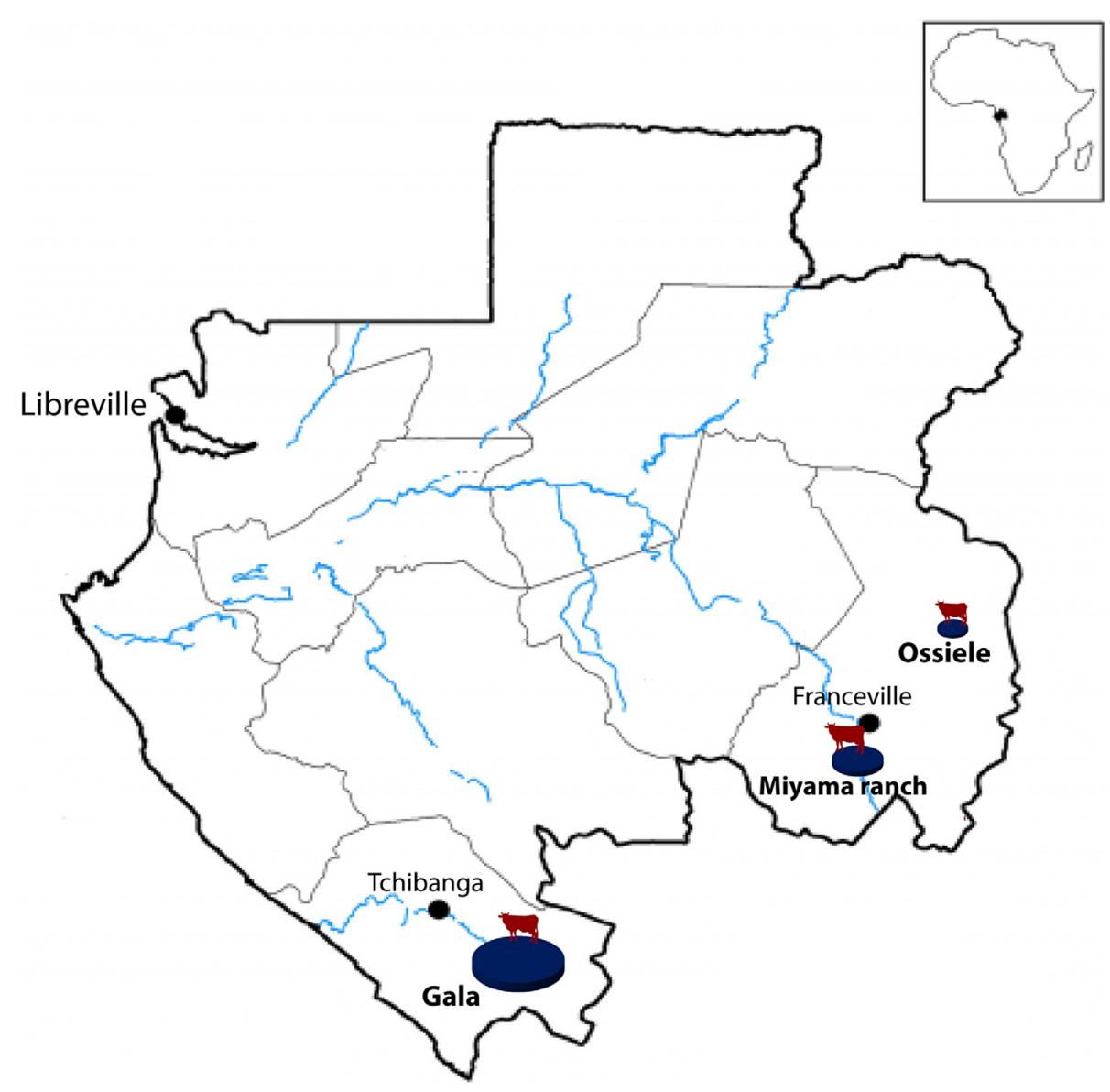

Figure 1. Map of Gabon with the location of sampling sites. The three study areas are shown with blue circles. The diameter of the circles is proportional to the numbers of animals bred in each area.

of 10X PCR buffer (Platinum ${ }^{\circledR}$ Taq DNA Polymerase, Invitrogen), $2 \mu \mathrm{L}$ of dNTP $(10 \mu \mathrm{M}$ each $), 2 \mu \mathrm{L} \mathrm{MgCl}_{2}$ $(50 \mathrm{mM}), 0.24 \mu \mathrm{L}$ of each primer $(10 \mu \mathrm{M}), 0.3 \mu \mathrm{L}$ enzyme Platinum Taq (Platinum ${ }^{\circledR}$ Taq DNA Polymerase, Invitrogen), $12.72 \mu \mathrm{L}$ of RNAse-free water (Invitrogen), and $5 \mu \mathrm{L}$ of DNA. Amplification generally involved $5 \mathrm{~min}$ at $95^{\circ} \mathrm{C}$ followed by 40 cycles of $1 \mathrm{~min}$ at $95^{\circ} \mathrm{C}, 1 \mathrm{~min}$ at $60^{\circ} \mathrm{C}$, and $1 \mathrm{~min}$ at $72{ }^{\circ} \mathrm{C}$ followed by a final elongation at $72{ }^{\circ} \mathrm{C}$ for $10 \mathrm{~min}$. The PCR products of approximately 700 base pairs (bp), characteristic of T. congolense, were subjected to T. congolense subtype-specific PCR to distinguish them between Forest, Savannah, and Kilifi. The primer sets used are shown in Table 1. The PCR conditions are the following for all three PCRs: $5 \mathrm{~min}$ at $95{ }^{\circ} \mathrm{C}$ followed by 35 cycles including $1 \mathrm{~min}$ at $95{ }^{\circ} \mathrm{C}, 1 \mathrm{~min}$ at $55^{\circ} \mathrm{C}$, and $1 \mathrm{~min}$ at $72{ }^{\circ} \mathrm{C}$ followed by a final elongation at $72{ }^{\circ} \mathrm{C}$ for $10 \mathrm{~min}$.

\section{Sequence analysis and phylogenetic analysis}

Sequence cleaning and assembling of contigs was conducted in ChromasPro 1.5. The nucleotide sequences were compared to those available in the public database using the algorithm "Blastn" of the NCBI BLAST [1]. Phylogenetic analyses were conducted to infer the relationship with other Trypanosoma spp. The sequence alignment was performed using the multiple sequence alignment program, ClustalW, contained in MEGA 5 [28]. A neighbor-joining tree was constructed using a Kimura 2-parameter substitution model, with bootstrap values calculated for 1000 replicates. The new sequences were deposited in GenBank with Accession Numbers KX452152-KX452176.

\section{Statistical analysis}

Analyses were performed using R software version 3.1.0 (Development Core Team 2014, USA). The chi-square $\left(\chi^{2}\right)$ test of Pearson was used for the comparison of the proportions of animals infected by different trypanosome species between study areas.

\section{Results}

Twenty-nine rDNA sequences were generated from cattle samples in this study. Blast analysis confirmed that close matches were found with $T$. congolense and $T$. vivax, respectively, for the sequences of 710- and 250-bp products.

Twenty-five of 29 sequences generated in this study were included in the phylogenetic analysis. The T. vivax sequence obtained from cattle from the Miyama ranch shared $77 \%$ 
Table 1. Primers used for detection of trypanosomes.

\begin{tabular}{|c|c|c|c|}
\hline Primers & Sequences & Trypanosomes & $\overline{\text { Size }(b p)}$ \\
\hline ITS $1 \mathrm{CF}$ & 5'- CCGGAAGTTCACCGATATTG -3' & T. congolense & $620-710$ \\
\hline \multirow[t]{4}{*}{ ITS1 BR } & $5^{\prime}$ - TTGCTGCGTTCTTCAACGAA - $3^{\prime}$ & T. brucei $b$. & 480 \\
\hline & & T. evansi & 480 \\
\hline & & T. vivax & 250 \\
\hline & & T. simiae & 400 \\
\hline TCF 1 & 5'-GGACACGCCAGAAGGTACTT-3' & T. congolense forest & 350 \\
\hline TCF 2 & $5^{\prime}$-GTTCTCGCACCAAATCCAAC-3' & & \\
\hline TCS 1 & $5^{\prime}$-CGAGCGAGAACGGGCAC-3' & T. congolense savannah & 316 \\
\hline TCS 2 & $5^{\prime}$-GGGACAAACAAATCCCGC-3' & & \\
\hline TCK 1 & 5'-GTGCCCAAATTTGAAGTGAT-3' & T. congolense kilifi & 294 \\
\hline TCK 2 & $5^{\prime}$-ACTCAAAATCGTGCACCTCG-3' & & \\
\hline
\end{tabular}

identity with the $T$. vivax reference sequence from a cow from Burkina Faso (JX910370), and 69\% identity with four other sequences from cows from Burkina Faso (JX910372, JX910375, JX910376, and JX910379). In the phylogenetic tree reconstructions, based on the nucleotide sequences of the ITS1 region of the ribosomal DNA, the Gabonese T. congolense strains from the Gala section grouped into two major clusters. Cluster I comprised $14 T$. congolense strains belonging to the Savannah subtype; whereas $10 \mathrm{~T}$. congolense strains from Gabon and three other strains, including one from Kenya (FJ712718), were grouped within cluster II, bringing together strains belonging to the Forest subtype (Fig. 2). T. congolense sequences from cluster I shared 34-76\% identity. The $T$. congolense variants grouped within cluster II displayed $43-77 \%$ identity with each other at the nucleotide level. These 10 T. congolense sequences shared 39-65\% identity with the Kenyan reference sequence (FJ712718) and 37-64\% with the reference sequence JX910374 from a cow from Burkina Faso.

The screening of 224 samples from N'dama cattle, including 110 from the Gala section, 100 from the Miyama ranch, and 14 from Ossiele, with conventional ITS1 PCR revealed an overall prevalence of $32.14 \%$ (95\% CI: $26.03-$ 38.3) (72/224). All the animals sampled appeared healthy and had received treatment against trypanosomosis at least four months before the beginning of the sampling. The infection rates in N'dama from the Gala section, the Miyama ranch, and Ossiele were 57.3\% (95\% CI: 48.03-66.5) (63/110), 4\% (95\% CI: $0.2-7.8)(4 / 100)$, and $35.7 \%$ (95\% CI: $10.6-60.8)$ $(5 / 14)$, respectively (Table 2$)$. The infection rate of trypanosomosis between the areas showed significant differences $\left(\chi^{2}=68.24, \mathrm{ddl}=2, p<0.001\right)$. The overall rates of infection with $T$. congolense and T. vivax were $25 \%$ (95\% CI: $19.3-30.7)$ and $7.1 \%$ (95\% CI: 3.8-10.5), respectively (Table 2). Five out of $224(2.3 \%)$ N'dama had mixed infections (T. congolense/ T. vivax). Mixed infections were detected in cattle from Gala. T. congolense was the dominant species across the Gala and Ossiele areas, with rates of infection of $47.3 \% \quad(95 \%$ CI: 37.9-56.6) and $28.6 \%$ (95\% CI: 4.9-52.2), respectively. The rates for $T$. vivax in the same areas were only $10 \%$ and $7.1 \%$, respectively. No mixed infections were detected in cattle from Ossiele. According to the chi-squared test,
T. congolense was significantly more prevalent than $T$. vivax $\left(\chi^{2}=26.48, \mathrm{ddl}=1, p<0.001\right)$. Only one trypanosome species was identified in infected animals from the Miyama ranch, namely $T$. vivax, with an infection rate of $4 \%$ (Table 2).

The $T$. congolense-positive samples $(n=56)$ were then screened using a specific PCR for the three subgroups of T. congolense: T. congolense savannah, T. congolense forest, and $T$. congolense kilifi. T. congolense savannah was the dominant subgroup with 35 animals infected (62.5\%) followed by $T$. congolense forest with 5 infected animals $(8.9 \%)$. The $T$. congolense savannah subgroup is significantly more predominant $\left(\chi^{2}=35, \mathrm{ddl}=1, p<0.001\right)$ than the T. congolense forest subgroup in Gala and Ossiele. Furthermore, 16 of $56(28.6 \%)$ animals had mixed infections with both subgroups. No infection with the T. congolense kilifi subgroup was discovered.

\section{Discussion}

Prevalence of bovine trypanosomosis and molecular identification of trypanosome species were studied in three cattle farming areas in the south of Gabon, namely the Gala section of the Nyanga ranch, the Miyama ranch, and Ossiele. Phylogenetic analysis was conducted in order to confirm the BLAST results and therefore the identity of the nucleotide sequences obtained. The phylogenetic tree showed that the variants of $T$. congolense, all from the Gala section, displayed considerable genetic variation and were classified into two major clusters. T. congolense genetic variants have also been reported in East and West Africa [3, 8]. The identification of this $T$. congolense genetic diversity in the same geographical area indicates the existence of various isolates. As suggested by Auty et al. [3], this genetic diversity cannot be explained only by geographical variation. In the Gala section, cattle are frequently in contact with many other wild animal species, suggesting the possibility of a transfer of strains specific to these wildlife host species [3] through specific species of tsetse. For example, host-specific strains of $T$. theileri were identified in cattle and water buffalo in the same geographical areas [23]. T. vivax obtained from cattle from the Miyama ranch shared $69-77 \%$ identity with $T$. vivax strains from cows 


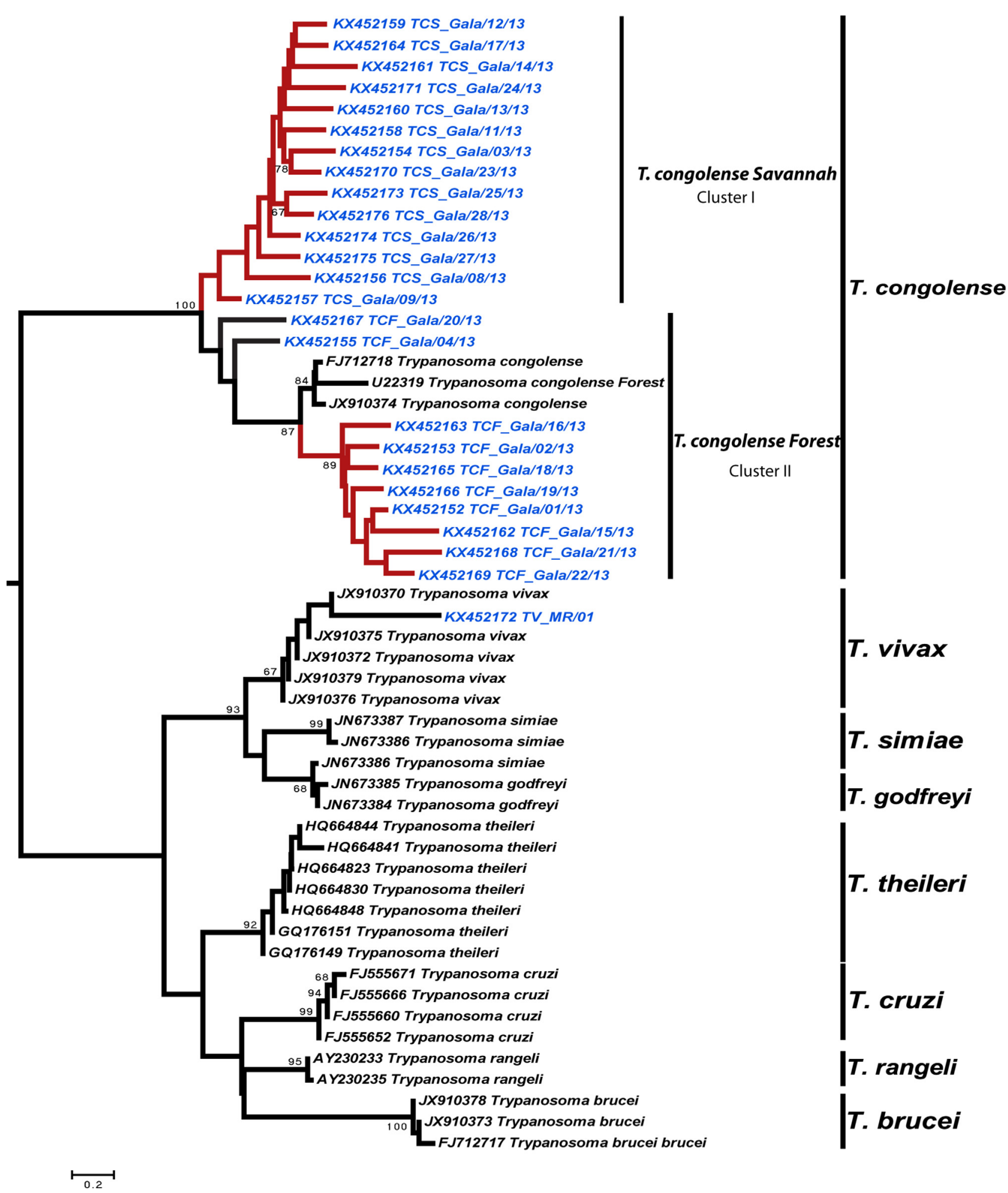

Figure 2. Phylogenetic tree based on partial ITS1 trypanosome sequence analysis. The tree was visualized with FigTree 1.3.1. Bootstrap values are shown to the left of the branch. Bootstrap values are shown where support is $>65 \%$. Sequences generated in this study are shown in blue. Sequences retrieved from GenBank are shown in black with their GenBank accession number.

from Burkina Faso. Indeed, domestic ruminants would be likely to share similar parasites. The position of strains KX452167 TCF_Gala/20/13 and KX452155 TCF_Gala04/13 on the phylogenetic tree suggests that they are variants of
T. congolense forest rather than two hybrid strains between $T$. congolense savannah and T. congolense forest. Additional bioinformatics analyses and analyses of recombination events would be necessary. 
Table 2. Prevalence of trypanosomosis in study areas and results of molecular characterization of trypanosome species infecting domestic cattle.

\begin{tabular}{|c|c|c|c|c|c|}
\hline \multirow[t]{2}{*}{ Sites } & \multirow[t]{2}{*}{ Total } & \multirow[t]{2}{*}{ No. total positive ITS1 (\%) } & \multicolumn{3}{|c|}{ Positive ITS1 PCR (\%) } \\
\hline & & & $\mathrm{TC}$ & TV & TC-TV \\
\hline Gala & 110 & $63(57.3)$ & $52(47.3)$ & $11(10)$ & $5(4.5)$ \\
\hline Ranch Miyama & 100 & $4(4)$ & 0 & $4(4 \%)$ & 0 \\
\hline Ossiele & 14 & $5(35.7)$ & $4(28.6)$ & $1(7.1 \%)$ & 0 \\
\hline Total & 224 & $72(32.14)$ & $56(25)$ & $16(7.1)$ & $5(2.2)$ \\
\hline
\end{tabular}

TC: Trypanosoma congolense; TV: Trypanosoma vivax; TC-TV: mixed infection with Trypanosoma congolense and Trypanosoma vivax.

The molecular prevalence of trypanosomosis was significantly higher in the Gala section than in Ossiele and the Miyama ranch. Out of the 224 N'dama cattle studied, 72 were found PCR positive with trypanosomes, with an overall prevalence of infection of $32.14 \%$. This result was higher than the one found in the cattle in Ghana, using parasitological methods (1.88\%) and serology (22.08\%) [9], and in the cattle in Northwest Ethiopia using parasitological methods (5.43\%) [15]. Otherwise, Nimpaye et al. [21] found an infection rate of $27.08 \%$ in domestic animals in Cameroon, using PCR assays. Moreover, Takeet et al. [27] detected 15.1\% positive infection with trypanosomes in cattle from Nigeria, using microscopy, while PCR detected $63.7 \%$ positive infections. The highest infection rate was found in Gala (57.3\%) followed by Ossiele (35.7\%) and the Miyama ranch (4\%). Indeed, in these three areas, the vegetation is made of savannah and plains crossed by numerous forest galleries and dotted with dense groves. However, the number and proximity of watercourses differ. The Gala section contains several watercourses including rivers and streams. These watercourses, surrounded by moist and shaded forest galleries [29], are shelters for tsetse flies. However, in the Miyama ranch, the watercourses bordering the area are located in distant hilly areas making it difficult to access for animals. The low infection rate found in the cattle from the Miyama ranch could therefore be explained by less frequent contacts between cattle and tsetse flies for the above reasons. Furthermore, the absence of $T$. congolense can probably be due to the absence of a biologically competent vector.

Two species of pathogenic trypanosomes have been identified, namely $T$. congolense and $T$. vivax. These two trypanosome species are the main agents of nagana [25]. The presence of these two species in Gabon has been highlighted by an entomological study in the Nyanga valley [29], and in tsetse flies captured during an active outbreak of human trypanosomosis in Komo Mondah [13] and a historic outbreak in Bendjé, in the Ogooué-Maritime Province in western Gabon $[11,12]$. In Gala, T. congolense and T. vivax were identified. These findings support those of Taufflieb [29], who identified these two species in Glossina palpalis palpalis in the Nyanga valley with an infection rate of $3 \%$ and $2 \%$, respectively. In addition, mixed infections with both trypanosome species have also been identified (4.5\%). In the cattle from Ethiopia, T. congolense was found to be the dominant species $(66.7 \%)$, compared to $T$. vivax $(9.3 \%)$ [22], and $19.4 \%$ were mixed infections. According to Taufflieb [29], in the Nyanga area,
G. p. palpalis is the main tsetse fly vector of trypanosomosis. The G. p. palpalis species lives in secondary forest, in vegetation along streams and swamps [31]. In the Miyama ranch, only $T$. vivax was found. This species was already identified by parasitological methods, with an infection rate of $26 \%$ in cattle from a ranch located in the south-east of Gabon [14]. The tsetse fly of the Fusca group, G. tabaniformis, was responsible for the transmission of T. vivax in this area [14]. Although a competent vector is present in the area, T. vivax can also be found outside of the area of distribution of tsetse because it can be transmitted mechanically by flies from the Tabanidae, Stomoxyinae, and Hippoboscidae families [10, 18].

The overall prevalence of T. vivax $(7.1 \%)$ was lower than that found in cattle and other domestic animals [20, 21, 24, 27]. However, the overall prevalence of $T$. congolense (25\%) was high in contrast to that previously reported in other domestic animals [20, 21, 24]. The very low prevalence of $T$. vivax with respect to $T$. congolense would indicate a low transmission of T. vivax in the studied localities, which is better controlled by animals because their genetic diversity is more limited than those of T. congolense and T. brucei [2]. The prevalence of T. vivax found in this study using the primers ITS1 CF and ITS1 BR is much lower than that obtained by Leak et al. [14] from cattle reared in the same area, using parasitological methods. This difference could be explained, on the one hand, by the improvement over recent years of curative and preventive treatments against trypanosomes, and on the other by the lower sensitivity of ITS1 CF and BR ITS1 primers for T. vivax compared to species-specific primers [22].

The subtyping of $T$. congolense allowed us to determine the circulation of two subgroups out of three in the Gala section and Ossiele, including T. congolense savannah and T. congolense forest, respectively, with overall infection rates of $62.5 \%$ (57.14\% and 5.36\% in Gala and Ossiele) and $8.9 \%$ (7.14\% and $1.79 \%)$. Multiple subgroups of T. congolense have already been found in multiple ecosystems, and in the same location [16]. Mixed infections with T. vivax and T. congolense were found. Mixed infections with multiple species of trypanosomes have previously been reported [17]. The infection of cattle with these two pathogenic species exacerbates disease severity even in trypanotolerant cattle. Mixed infections by the two subgroups were also detected (28.6\%). In Gabon, the T. congolense forest subgroup was predominant in the outbreak of Bendjé, in western Gabon [11]. The infection rate with the forest subgroup found in this study is higher than that found in Cameroon, a neighboring country, 
by Nimpaye et al. [21] in domestic animals. The savannah subgroup exhibits a greater virulence than the other two subgroups, experimentally demonstrated in cattle and mice $[4,5]$.

Further studies are needed to determine the real prevalence of T. vivax and the active potential of the infection. Indeed, these findings should be coupled with measurements of packed cell volume or a microscopic confirmation or with another tool, to determine (i) the risk of trypanosomosis in the main breeding areas of this country in Central Africa, because of the co-circulation of these two pathogenic species of trypanosomes, and (ii) the need to increase control measures for trypanosomosis in livestock breeding areas in Gabon, because although trypanotolerant, N'dama cattle could be a reservoir for these two parasites (T. vivax and T. congolense) and therefore a risk for programs targeting the elimination of animal trypanosomosis in the region and an obstacle to the introduction of other more trypanosusceptible but productive cattle breeds. On the other hand, these trypanotolerant cattle can be reared in such tsetse infested areas. This is an enormous advantage compared to other breeds, and it shows that they represent a key in biodiversity which has to be promoted.

\section{Conflict of interest}

The authors declare that they have no conflict of interest.

Acknowledgements. We thank SIAT-Gabon, especially Bruno Besnard and Ernest Agossou. We acknowledge the Smithsonian Institute for material assistance, Heidi Lançon for the English revision, and Gustave Simo and Antoine Mitte Mbeang Beyeme. The CIRMF is supported by the Government of Gabon, TotalFina-Elf Gabon, and the Ministère de la Coopération Française.

\section{References}

1. Altschul SF, Lipman DJ. 1990. Protein database searches for multiple alignments. Proceedings of the National Academy of Sciences of the United States of America, 87(14), 5509-5513.

2. Authié E, Bringaud F, Bakalara N, Tetaud E, Baltz T. 1999. Trypanosomoses humaines et animales: Maladie du sommeil et Nagana. Annales de l'Institut Pasteur, 10(1), 27-50.

3. Auty H, Anderson NE, Picozzi K, Lembo T, Mubanga J, Hoare R, Fyumagwa RD, Mable B, Hamill L, Cleaveland S, Welburn SC. 2012. Trypanosome diversity in wildlife species from the Serengeti and Luangwa Valley ecosystems. PLoS Neglected and Tropical Diseases, 6(10), e1828.

4. Bengaly Z, Sidibé I, Boly H, Sawadogo L, Desquesnes M. 2002. Comparative pathogenicity of three genetically distinct Trypanosoma congolense-types in inbred Balb/c mice. Veterinary Parasitology, 105(2), 111-118.

5. Bengaly Z, Sidibé I, Ganaba R, Desquesnes M, Boly H, Sawadogo L. 2002. Comparative pathogenicity of three genetically distinct types of Trypanosoma congolense in cattle: clinical observation and haematological changes. Veterinary Parasitology, 108(1), 1-19.

6. Desquesnes M, Dia ML. 2003. Trypanosoma vivax: Mechanical transmission in cattle by one of the most common African tabanids, Atylotus agrestis. Experimental Parasitology, 103(1-2), 35-43.

7. Desquesnes M, Tresse L. 1996. Évolution de la sensibilité de la PCR pour la détection de l'ADN de Trypanosoma vivax selon divers modes de préparation des échantillons sanguins. Revue d'Élevage et de Médecine Vétérinaire des Pays Tropicaux, 49, 322-327.

8. Gashumba JK, Baker RD, Godfrey DG. 1988. Trypanosoma congolense - the distribution of enzymic variants in East African and West Africa. Parasitology, 96, 475-486.

9. Ingabire C. 2009. Trypanosomose bovine au Ghana : Prévalences sérologique et parasitologique; intérêt de l'utilisation du système d'information géographique. Master of Sciences Thesis: EISMV, Dakar, Sénégal. p. 30.

10. Itard J. 2000. Trypanosomoses animales africaines, in Précis de parasitologie vétérinaire tropicale. Edition Tec \& Doc: Londres, New York, Paris. p. 206-450.

11. Kohagne Tongué L, Gounoue Kamkuimo R, Kaba D, Mengue M'Eyi P, Mimpfoundi R, Louis FJ. 2011. Enquête entomologique dans le foyer historique de trypanosomose humaine africaine de Bendjé au Gabon. Parasite, 18, 303-309.

12. Kohagne Tongué L, Mengue M'Eyi P, Mimpfoundi R, Louis FJ. 2010. Entomological patterns in the human African trypanosomiasis trypanosomosis focus of Komo Mondha, Gabon. African Health Sciences, 10(4), 341-348.

13. Kohagne Tongué L, Mengue M'Eyi P, Mimpfoundi R, Louis FJ. 2010. Régime alimentaire des glossines et diversité des espèces de trypanosomes dans un foyer actif de trypanosomose humaine africaine au Gabon. Bulletin de la Société de Pathologie Exotique, 103(4), 264-271.

14. Leak SGA, Colardelle C, D'Ieteren G, Dumont P, Feron A, Jeannin P, Minengu M, Mulungu M, Ngamuna S, Ordner G, Sauveroche B, Trail JCM, Yangari G. 1991. Glossina fusca group tsetse as vectors of cattle trypanosomiasis trypanosomosis in Gabon and Zaire. Medical Veterinary and Entomology, 5(1), 111-120.

15. Lelisa K, Damena D, Kedir M, Feyera T. 2015. Prevalence of bovine trypanosomosis and apparent density of tsetse and other biting flies in Mandura District, Northwest Ethiopia. Journal of Veterinary Sciences and Technology, 6, 229.

16. Malele I, Craske L, Knight C, Ferris V, Njiru Z, Hamilton P, Lehane S, Lehane M, Gibson W. 2003. The use of specific and generic primers to identify trypanosome infections of wild tsetse flies in Tanzania by PCR. Infection, Genetics and Evolution, 3, 271-279.

17. Malele II, Magwisha HB, Nyingilili HS, Mamiro KA, Rukambile EJ, Daffa JW, Lyaruu EA, Kapange LA, Kasilagila GK, Lwitiko NK, Msami HM, Kimbita EN. 2011. Multiple Trypanosoma infections are common amongst Glossina species in the new farming areas of Rufiji district, Tanzania. Parasites \& Vectors, 4, 217.

18. Mavoungou JF, Jay-Robert P, Gilles J, Atsame Edda A, Duvallet G. 2008. Écologie des Stomoxes (Diptera: Muscidae) au Gabon. I - Premier inventaire dans différentes zones écologiques. Parasite, 15, 27-34.

19. Mihok S, Machika C, Darji N. 1995. Kang'ethe EK, Otieno LH. 1995. Relationships between host blood factors and proteases in Glossina morsitans subspecies infected with Trypanosoma congolense. Medical and Veterinary Entomology, 9(2), 155-160. 
20. Nakayima J, Nakao R, Alhassan A, Mahama C, Afakye K, Sugimoto C. 2012. Molecular epidemiological studies on animal trypanosomiases in Ghana. Parasites \& Vectors, 5, 217.

21. Nimpaye H, Njiokou F, Njine T, Njitchouang G. 2011. Trypanosoma vivax, Trypanosoma congolense forest and Trypanosoma simae: prevalence in domestic animals of sleeping sickness foci of Cameroon. Parasite, 18(2), 171-179.

22. Njiru Z, Constantine C, Guya S, Crowther J, Kiragu JM, Thompson RC, Dávila AM. 2005. The use of ITS1 rDNA PCR in detecting pathogenic African trypanosomes. Parasitology Research, 95(3), 186-192.

23. Rodrigues AC, Paiva F, Campaner M, Stevens JR, Noyes HA, Teixeira MMG. 2006. Phylogeny of Trypanosoma (Megatrypanum) theileri and related trypanosomes reveals lineages of isolates associated with artiodactyl hosts diverging on SSU and ITS ribosomal sequences. Parasitology, 132, 215-224.

24. Salim B, Bakheit MA, Kamau J, Nakamura I, Sugimoto C. 2011. Molecular epidemiology of camel trypanosomiasis trypanosomosis based on ITS1 rDNA and RoTat 1.2 VSG gene in the Sudan. Parasites \& Vectors, 4, 31.

25. Solano P, Bouyer J, Itard J, Cuisance D. 2010. Cyclical vectors of trypanosomosis, in Infectious and parasitic diseases of livestock. Lefèvre P-C, Blancou J, Chermette R, Uilenberg G, Editors. vol. 1, Éditions Lavoisier (Tec \& Doc): Paris. p. $155-183$.

26. Sumba AL, Mihok S, Oyieke FA. 1998. Mechanical transmission of Trypanosoma evansi and T. congolense by Stomoxys niger and $S$. taeniatus in a laboratory mouse model. Medical and Veterinary Entomology, 12, 417-422.
27. Takeet MI, Fagbemi BO, De Donato M, Yakubu A, Rodulfo HE, Peters SO, Wheto M, Imumorin IG. 2013. Molecular survey of pathogenic trypanosomes in naturally infected Nigerian cattle. Research in Veterinary Science, 94, 555-561.

28. Tamura K, Peterson D, Peterson N, Stecher G, Nei M, Kumar S. 2001. MEGA5: molecular evolutionary genetics analysis using maximum likelihood, evolutionary distance and maximum parsimony methods. Molecular Biology and Evolution, 28(10), 2731-2739.

29. Taufflieb R. 1963. Rapport d'une enquête sur les glossines et les trypanosomoses animales de la vallée moyenne de la Nyanga. $\mathrm{http} / /$ horizon.documentation.ird.fr/exl-doc/pleins_textes/pleins_ textes_5/b_fdi_08-09/10604.pdf.

30. Van den Bossche P, Shumba W, Njagu C, Shereni W. 2001. The distribution of bovine trypanosomosis in Zimbabwe and an evaluation of the value of an anti-trypanosomal antibody detection ELISA as a tool for monitoring the effectiveness of tsetse control operations. Tropical Animal Health and Production, 33(5), 391-405.

31. Verdier C. 2005. Étude expérimentale des effets de la moxidectine sur Glossina palpalis gambiensis et Glossina morsitans morsitans. Thèse d'exercice, École Nationale Vétérinaire de Toulouse-ENVT, Toulouse, France. p. 175.

32. Zinga Kouma RC, Bouyer J, Mavoungou JF, Acapovi Yao GL, Kohagne Tongué L, Mbang Nguema OA, Ondo KPO, Mutambwe S. 2013. Évaluation de la diversité des diptères hématophages dans une clairière marécageuse du Gabon à l'aide des pièges Vavoua et Nzi. Revue d'Élevage et de Médecine Vétérinaire des Pays Tropicaux, 66(3), 91-96.

Cite this article as: Maganga GD, Mavoungou J-F, N'dilimabaka N, Moussadji Kinga IC, Mvé-Ondo B, Mombo IM, Ngoubangoye B, Cossic B, Mikala Okouyi CS, Souza A, Leroy EM, Kumulungui B \& Ollomo B: Molecular identification of trypanosome species in trypanotolerant cattle from the south of Gabon. Parasite, 2017, 24, 4.

Reviews, articles and short notes may be submitted. Fields include, but are not limited to: general, medical and veterinary parasitology; morphology, including ultrastructure; parasite systematics, including entomology, acarology, helminthology and protistology, and molecular analyses; molecular biology and biochemistry; immunology of parasitic diseases; host-parasite relationships; ecology and life history of parasites; epidemiology; therapeutics; new diagnostic tools.

All papers in Parasite are published in English. Manuscripts should have a broad interest and must not have been published or submitted elsewhere. No limit is imposed on the length of manuscripts.

Parasite (open-access) continues Parasite (print and online editions, 1994-2012) and Annales de Parasitologie Humaine et Comparée (1923-1993) and is the official journal of the Société Française de Parasitologie. 